Print ISSN: 2233-4165 / Online ISSN: 2233-5382

doi:http://dx.doi.org/10.13106/ijidb.2017.vol8.no5.7.

\title{
Output and Real Exchange Rate in Developing Countries: Evidence from China
}

\author{
Xingang Huan*, Yugang $\mathrm{He}^{* *}$ \\ Received: June 29, 2017. Revised: August 21, 2017. Accepted: October 15, 2017.
}

Abstract

Purpose - The purpose of this paper is to analyze the relationship between the real exchange rate and the output, which is based on the macroeconomic equilibrium theory in China. Its aim will be to verify whether the change in the real exchange rate has a significant effect on the output or not.

Research design, data, and methodology - This study endeavors triestoinvestigatethecorrelationamongeconomicvariablesunder the macroeconomic market (the commodity market and the money market) equilibrium. So, time-series data from 1990 to 2016 is applied to establish a vector auto-regression (VAR) model so as to perform an empirical analysis.

Results - The empirical results reveal that an increase in the real exchange rate will result in an increase in the output in the short run. However, the empirical results also indicate that this kind of mechanism cannot work in the long run.

Conclusions - The effect of a decrease of real exchange rate on output is significant in the short run. Also, this paper suggests that the total supply and the total demand can promote economic growth. The fiscal and money policy play a significant role in economic growth in China as well.

Keywords: Real Exchange Rate, Economic Growth, VAR Model.

JEL Classifications: C32, C51, D51, E20.

\section{Introduction}

On January 20th, 2017, Donald Trump sworn in as the president of the United States of America. President Donald Trump declared China is the "grand champions" of currency manipulation soon after coming into office. In other word, Donald Trump's speech tells how important the exchange rate is.

In the open economy, the fluctuation of the exchange rate not only leads to the change of the equilibrium home and abroad but also result in the change of the investment, consumption, price, money supply and so on. Nowadays, there are lots of governments facing the domestic deflation. Most of them tend to use an increase in foreign exchange rate to stimulate the economic growth. However, a lot of literature have shown that an increase in the exchange rate cannot result in an increase in output. Conversely, it may depress the economic growth. China as a developing country, it is still a question that an increase in the

* First Author, 2016SB005, 32400217, Grain Economics Research Center, School of Economics and Trade, Henan University of Technology, China. E-mail: luckyhxg@163.com

** Corresponding Author, Department of International Trade, Chonbuk National University, Korea. E-mail: 1293647581@jbnu.ac.kr exchange rate can result in an increase in the output can work or not. Because the nominal exchange rate is affected by many factors such as price level and exchange rate regime, it is hard to reflect the money's real value of a country accurately, and it is difficult to connect it with the output objectively. However, the real exchange rate can reflect the money's real value of a country. Also, it reveals a country's competitiveness in the international trade. And it can have a good connection with the macroeconomic variables. Thus, this paper tries to explore correlation between the real exchange rate and the economic growth in China.

As a matter of fact, macroeconomic variables such as the investment, consumption, price and money supply can affect the fluctuation of the foreign real exchange rate in China. Meanwhile, the real exchange rate also interact the macroeconomic variables. The purpose of this paper is to reveal the relationship between the real exchange rate and the economic growth. In order to address this relationship well, the output, the price, the wage, the government purchase, the money supply and the real exchange rate are applied to established VAR model. And it is performed to solve the question that an increase in the exchange rate can result in an increase in the output, works in China or not. 


\section{Literature Review}

There is a vast body of empirical literature on the relationship between the real exchange rate and the output. In many of the existing studies, it has been recognized that an increase in the real exchange rate can result in an increase in the output in the short run in the developed counties. However, only few studies focus on the developing countries in the short run.

Bahmani-Oskooee and Kandil (2008) evaluate the effects of exchange rate depreciation on output growth for a sample of fourteen MENA countries. By applying cointegration and error correction modeling, they differentiated the growth effects of deprecation in the short run and long run. They also distinguish the anticipated and unanticipated components of real exchange rate. Their results indicate that anticipated depreciation is expansionary for Bahrain, Oman, Saudi Arabia, Syria and Tunisia (2008) but contractionary for Lebanon and Libya in the long run. Unanticipated depreciation has no expansionary effect in the long run while it is only evident in the short run. In contrast, it has a contractionary effect in Jordan, Kuwait and Qatar in the long run. With similar empirical methods, in 2006, Ardıç (2006) shows that real exchange rate shocks are important in real output variations and real depreciation leads to contraction of the output in Turkey.

A few studies examine the balance sheet effect of real depreciations using cross-country panel data methods. Also, by incorporating interaction terms to their panel data growth model, Bebczuk, Galindo, and Panizza (2006) evaluate whether foreign currency denominated debt is important for the effect of real depreciation on GDP growth. Based on a sample of 57 countries (35 developing, 22 industrial) for the period of 1976-2003, they find that in countries with no dollarization, a 20 percent real devaluation increases per capita GDP growth by approximately half of a percentage point. As dollarization increases, the expansionary effect of devaluations diminishes. When the dollar denominated external debt exceeds 84 percent of GDP, devaluations become contractionary. Similarly, Bleaney, and Vargas (2009) analyze the relationship between net capital inflows, real exchange rate movements and growth for twenty emerging markets and twelve developed countries over the period 1983-2004. In order to examine valuation effects that arise from foreign indebtedness, they construct a debtweighted real exchange rate. Their results show that real exchange rate depreciations tend to be contractionary in emerging markets, whereas they are expansionary in developed countries and this finding is not only valid for crisis periods. They also point out that the debt-weighted real effective exchange rate rather than the trade-weighted one is associated with the contractionary devaluation hypothesis which indicates that it is the result of valuation effects on foreign debt. Blecker and Razmi (2008) test the twin hypotheses-Fallacy of Composition and Contractionary
Devaluation empirically, utilizing from a data of 18 developing 24 countries and 10 industrialized countries covering the years 1983-2004.12 They choose all major developing countries for which manufactures constitute more than $70 \%$ of total exports as of 2000 . Their results suggest that real depreciations for these developing countries relative to the industrial countries are contractionary. Moreover, contractionary effects are stronger in the subsample of countries with high external debt burdens than for the less indebted countries. Rodrik (2008) provides empirical evidence for the positive growth effects of real exchange rate undervaluation for a panel data sample of 184 countries. The distinguishing feature of Rodrik (2008) from previous studies analyzing the growth effects of real exchange rates is his undervaluation index used as the real exchange rate measure. In his undervaluation index, he adjusts the PPP which is based real exchange rate measure with BalassaSamuelson effect. According to Balassa and Samuelson, since the productivity in traded goods will be greater in developed countries, the non-traded goods will be more expensive in developed countries than in developing countries. Then the real exchange rate is expected to be lower in developed countries. Based on this argument, Rodrik corrects for the Balassa- Samuelson effect by regressing the real exchange rate on a variable related to the degree of development of each country (typically, real GDP per capita) and then defines undervaluation as the difference between the observed and the predicted real exchange rate. Using this Balassa-Samuelson adjusted index of undervaluation, Rodrik estimates panel data growth models for developing and developed countries by adopting Fixed Effects and Generalized Method of Moments estimators. His results show that undervaluation of currency stimulates economic growth especially for developing countries. He argues that the main mechanism behind this result is the tradable sector that, by increasing the profitability of the tradable sector which suffers disproportionately from the institutional weaknesses and market failures, undervaluation of the real exchange rate facilitates economic growth in developing countries. In 2009, Woodford heavily criticizes Rodrik mainly due to his undervaluation index, as the use of this index exaggerates the strength and the robustness of the effect of real exchange rate on growth.

Despite the criticisms on Rodrik's undervaluation index, some recent studies such as Gala, Di Nino, Eichengreen, and Sbracia, Rapetti, Scott and Razmi and Nouira and Sekkat, Gluzmann, Levy-Yeyati and In Sturzenegger conduct panel data analysis based on this undervaluation index. Mostly focusing on the theoretical channels through which real exchange rate levels can affect economic development, Gala finds a positive correlation between real exchange rate undervaluation and growth for a panel of 58 developing countries for the period 1960-1999. Gluzmann, Levy-Yeyati, and Sturzenegger (2012) explore the effect of undervalued 
currency on different components of GDP such as consumption, investment, saving, exports, imports and employment in order to determine the channels of this effect. They show that, for developing countries, undervaluation does not seem to affect the tradable sector by promoting exports or creating a substitution from imports but instead leads to greater domestic savings and investment, as well as employment. Di Nino, Eichengreen, and Sbracia (2011) extend Rodrik's study by using a more recent Penn World Tables dataset, by extending the time span which goes back to 1861 and by using alternative real exchange rate measures such as the WPI and CPI-based measures of PWT dataset. Their results verify the results of Rodrik. Rapetti, Scott, and Razmi (2012) modify the study of Rodrik by changing the definition of developing and developed country samples. They show that his finding is sensitive to the criterion used to divide the sample between developed and developing countries.

There are also some other studies which provide empirical support to the conventional effects of real exchange rate depreciation. Levy-Yeyati and Sturzenegger (2017) examine the evolution of the exchange rate regimes in recent years and point out that there is a tendency to intervene to depreciate local currency which they called as "fear of appreciation". Showing that these interventions managed to preserve a depreciated real exchange rate, they provide empirical evidence that this fear of appreciation leads to higher output and productivity growth which is not only restricted to short term cyclical changes but also leads to higher long term GDP growth. They also investigate the potential channels through which this effect works and showed that this positive effect of fear of appreciation comes from increased domestic savings and investment rather than export-led expansions or import substitution.

In conclusion, most of the econometric analyses indicate that devaluations (their increases in the level of the real exchange rate or in the rate of depreciation) are associated with a reduction in output. The few VAR studies reviewed above equally support the existence of a contractionary devaluation in the sampled countries. However, it can be observed that most cases of contractionary devaluations have been focused on Latin America and other developed nations. Only few studies had been conducted on the issue in Asian developing countries, particularly China. More importantly, there are few data on contractionary devaluation in China based on regression and simulation analyses. Our study intends to demonstrate the existence of contractionary devaluation in China by applying the restricted vector autoregressive model, drawing from previous studies conduct in the other countries reviewed above. This approach may enable to identify other shocks that might exert important influences on output in China. To achieve this objective, a six-variable VAR will be estimated (real exchange rate, nominal wage, money supply, gross domestic product, government purchase and price level).
$<$ Table 1> A summary of previous study

\begin{tabular}{|c|c|c|c|c|}
\hline Author & Year & Area & $\begin{array}{c}\text { Short-run } \\
\text { effect }\end{array}$ & $\begin{array}{c}\text { Long-run } \\
\text { effect }\end{array}$ \\
\hline Ardıç & 2006 & Developed country & Yes & Yes \\
\hline $\begin{array}{c}\text { Bebczuk, Galindo, } \\
\text { \& Panizza }\end{array}$ & 2006 & Developing country & No & Yes \\
\hline $\begin{array}{c}\text { Bebczuk, Galindo, } \\
\text { Panizza }\end{array}$ & 2006 & Developed country & No & Yes \\
\hline $\begin{array}{c}\text { Woodford } \\
\begin{array}{c}\text { Bahmani-Oskooee } \\
\text { \& Kandil }\end{array}\end{array} 22009$ & Developed country & No & Yes \\
\hline Blecker \& Razmi & 2008 & Developed country & No & Yes \\
\hline Rodrik & 2008 & Developed country & Yes & No \\
\hline Bleaney \& Vargas & 2009 & Developing country & No & Yes \\
\hline $\begin{array}{c}\text { Di Nino, } \\
\text { Eichengreen, } \\
\& \text { Sbracia }\end{array}$ & 2011 & Developed country & No & Yes \\
\hline $\begin{array}{c}\text { Gluzmann, } \\
\text { Levy-Yeyati, } \\
\text { \& Sturzenegger }\end{array}$ & 2012 & Developing country & No & Yes \\
\hline
\end{tabular}

Note: "Yes" represents that the real exchange rate has an effect on the output.

"No" represents that the real exchange rate has no effect on the output.

\section{Theoretical Model}

In the macroeconomic equilibrium theory, the macroeconomic market is basically composed by the commodity market and the money market. On the commodity market, if the total commodity supply is equal to the total commodity demand, the commodity market will arrive at an equilibrium; On the money market, if the total money supply is equal to the total money demand, the money market will also arrive at an equilibrium. And if both of them arrive at an equilibrium contemporarily, the macroeconomic equilibrium will be achieved. So, it means that an equilibrium relationship exists among the macroeconomic variables. The commodity market equilibrium shows below:

$$
\begin{aligned}
& \text { Totdd }=C+I \\
& N X=E X-I M \\
& Y=C+I+(E X-I M) \\
& Y=\text { Totdd }+N X \\
& N X=N X(\operatorname{Re} r)
\end{aligned}
$$

On equation (4), the national income identity is made up of the total demand and the net export. $Y$ stands for the national income; Rer stands for the real exchange rate. Moreover, $N X(\operatorname{Rer})$ stands for a function about the change of the net export and the real exchange rate. 


$$
\text { Tottd }=\alpha_{a a} R w-\alpha_{a b} R+\alpha_{a c} G
$$

On equation (6), it indicates that some factors affect the total demand. Rwstands for the real wage (a higher real wage will result in a higher consumption, which will lead to an increase in the total demand.); $R$ stands for the interest level (a higher interest will result in a lower investment, which will lead to a decrease in the total demand); $G$ stands for the government purchase (an increase in the government purchase will result in an increase in the total demand).

An equilibrium on the commodity market gives:

$$
Y=\alpha_{a a} R w-\alpha_{a b} R+\alpha_{a c} G+N X(\operatorname{Re} r)
$$

On the money market, the money supply is determined by the Central Bank. However, the money supply mainly satisfies the demand of the transaction, the demand of the precautionary motive money and the demand of the investment motive money. These kinds of money demand can be treated as the increasing function $Y$ and the decreasing function $R$.

That is:

$$
M^{d}=\alpha_{b a}-\alpha_{b b} R
$$

The money market arrives at an equilibrium. And it indicates that the money supply is equal to the money demand:

$$
M^{d}=M^{s}
$$

Therefore, the money market equilibrium gives:

$$
M^{s}=M^{d}=\alpha_{b a} Y-\alpha_{b b} R=M
$$

The real wage is the ratio of the nominal wage to the price level. So, when the commodity market and the money market arrive at an equilibrium at the same time, equation (6) can be written:

$$
\begin{aligned}
Y= & \frac{\alpha_{a a} \alpha_{b b}}{\alpha_{b b}+\alpha_{a b} \alpha_{b a}} \frac{W}{P}+\frac{\alpha_{a b}}{\alpha_{b b}+\alpha_{a b} \alpha_{b a}} M+ \\
& \frac{\alpha_{a c} \alpha_{b b}}{\alpha_{b b}+\alpha_{a b} \alpha_{b a}} G+\frac{\alpha_{b b}}{\alpha_{b b}+\alpha_{a b} \alpha_{a b} \alpha_{b a}} N X(\operatorname{Re} r)
\end{aligned}
$$

Based on equation (11), VAR models about the real exchange rate and the economic growth rate are established:

$$
\begin{aligned}
Y_{t}= & C_{1}+A_{y y}(\beta) Y_{t}+A_{w y}(\beta) W_{t}+A_{g y}(\beta) G_{t}+A_{\text {rery }}(\beta) \operatorname{Re} r_{t} \\
& +A_{m y}(\beta) M_{t}+A_{p y}(\beta) P_{t}+\varepsilon_{t}^{y}
\end{aligned}
$$

$$
\begin{aligned}
\operatorname{Re} r_{t}= & C_{2}+A_{y r e r}(\beta) Y_{t}+A_{\text {wrer }}(\beta) W_{t}+A_{\text {grer }}(\beta) G_{t} \\
& +A_{\text {rerrer }}(\beta) \operatorname{Re} r_{t}+A_{\text {mrer }}(\beta) M_{t}+A_{\text {prer }}(\beta) P_{t}+\varepsilon_{t}^{\text {rer }}
\end{aligned}
$$

Note: $A(\beta)=\alpha_{a} \beta+\alpha_{b} \beta^{2}+\alpha_{c} \beta^{3}+\alpha_{d} \beta^{4} \ldots \ldots$

\section{Empirical Analysis}

\subsection{Data description}

In this paper, six variables are involved. The real exchange $(\log R e r)$ is obtained from the Purchasing Power Parity, and its change can indicate its appreciation and depreciation; The nominal wage (log Wage) is the result that the average wage is multiplied by the quantity of employment, and it indicates the income level of national resident; The money supply $\left(\log M_{1}\right)$ is measured by $M_{1}$, and its magnitude can be controlled by the Central Bank; The national income $(\log G d p)$ is measured by $G D P$, and it indicates the domestic output; The government purchase $(\log G)$ is measured by national fiscal expenditure, and its magnitude is controlled by government; The price level $(\log C p i)$ is measured by the retail price index, and it indicates the current price level; In order to remove the outlier and to reduce the heteroscedasticity, all variables are taken logarithm. The definition, the function and the source of the variables are shown in <Table 2>.

<Table 2> Definition, function and source of variables

\begin{tabular}{|c|c|l|}
\hline Variable & Definition & \multicolumn{1}{|c|}{ Source } \\
\hline $\log R e r$ & $\begin{array}{c}\text { real exchange } \\
\text { rate }\end{array}$ & $\begin{array}{l}\text { National Bureau of statistics of the } \\
\text { People' s Republic of China }\end{array}$ \\
\hline $\log$ Wage & nominal wage & $\begin{array}{l}\text { National Bureau of statistics of the } \\
\text { People' s Republic of China }\end{array}$ \\
\hline $\log M_{1}$ & money supply & $\begin{array}{l}\text { National Bureau of statistics of the } \\
\text { People' s Republic of China }\end{array}$ \\
\hline $\log G d p$ & $\begin{array}{c}\text { gross domestic } \\
\text { product }\end{array}$ & $\begin{array}{l}\text { National Bureau of statistics of the } \\
\text { People' s Republic of China }\end{array}$ \\
\hline $\log G$ & $\begin{array}{c}\text { government } \\
\text { purchase }\end{array}$ & $\begin{array}{l}\text { National Bureau of statistics of the } \\
\text { People' s Republic of China }\end{array}$ \\
\hline $\log C p i$ & price level & $\begin{array}{l}\text { National Bureau of statistics of the } \\
\text { People' s Republic of China }\end{array}$ \\
\hline
\end{tabular}

\subsection{Unit root test}

When a time-series regression approach is used to study the relationship among time series, it is important to test the stationary of the original sequence first. The reason is that, even though the sequence is non-stationary, the result of the regression test finds that the relationship among the sequences may be notable. In fact, this kind of regression is spurious regression. Therefore, it is necessary to test the stationary of the logarithm sequence of variables. 
<Table 3> Unit root test

\begin{tabular}{|c|c|c|c|}
\hline Variable & ADF test statistic & P-value & Test critical value 5\% \\
\hline $\log$ Rer & -2.537 & 0.119 & -2.981 \\
\hline $\log$ Wage & -0.959 & 0.752 & -2.981 \\
\hline $\log M_{1}$ & -2.839 & 0.067 & -2.981 \\
\hline $\log G d p$ & -0.398 & 0.893 & -3.005 \\
\hline $\log G$ & -0.725 & 0.823 & -2.981 \\
\hline $\log C p i$ & -2.725 & 0.076 & -2.998 \\
\hline $\log$ Rer & -3.916 & 0.006 & -2.986 \\
\hline $\log$ Wage & -4.723 & 0.001 & -2.986 \\
\hline $\log M_{1}$ & -2.825 & 0.049 & -2.986 \\
\hline $\log G d p$ & -4.467 & 0.002 & -3.005 \\
\hline $\log G$ & -3.598 & 0.013 & -2.986 \\
\hline $\log C p i$ & -3.114 & 0.040 & -2.998 \\
\hline
\end{tabular}

Note: $D$ represents the first difference.

$<$ Table 3> reveals that the original sequences of all variables' logarithm form are non-stationary at $5 \%$ significance level. However, after the first difference, all of them become stationary at $5 \%$ significance level.

\subsection{Johansen cointegration test}

The Engel Granger Cointegration theorem implies that if variables' time-series exists cointegration, the linear combination of all variables' sequence will be stationary. Because $\log$ Rer, $\log$ Wage, $\log M_{1}, \log G d p, \log G$ and $\log C p i$ are the variables in the VAR model, the cointegration test is adopted as <Table $4>$ and $<$ Table $5>$ shown.

$<$ Table 4> Unrestricted cointegration rank test(trace)

\begin{tabular}{|c|c|c|c|c|}
\hline $\begin{array}{c}\text { Hypothesized } \\
\text { No. of CE(s) }\end{array}$ & Eigenvalue & Trace Statistic & $\begin{array}{c}\mathbf{0 . 0 5} \text { critical } \\
\text { value }\end{array}$ & Prob. \\
\hline None* $^{*}$ & 0.917 & 133.865 & 95.754 & 0.000 \\
\hline At most 1* & 0.680 & 74.169 & 69.819 & 0.022 \\
\hline At most 2 & 0.530 & 46.851 & 47.856 & 0.062 \\
\hline At most 3 & 0.427 & 28.728 & 29.797 & 0.053 \\
\hline At most 4 & 0.314 & 15.350 & 15.495 & 0.053 \\
\hline At most 5* & 0.231 & 6.301 & 3.841 & 0.012 \\
\hline
\end{tabular}

Trace test indicates 3 integration eqn(s) at the 0.05 level

* denotes rejection of the hypothesis at the 0.05 level.

** Mackinnon-Haug-Michelis(1999) p-values.

$<$ Table 5> Unrestricted cointegration rank test (Maximum Eigenvalue)

\begin{tabular}{|c|c|c|c|c|}
\hline $\begin{array}{c}\text { Hypothesized } \\
\text { No. of CE(s) }\end{array}$ & Eigenvalue & $\begin{array}{c}\text { Trace } \\
\text { Statistic }\end{array}$ & $\begin{array}{c}\mathbf{0 . 0 5} \\
\text { critical value }\end{array}$ & Prob. \\
\hline None $^{*}$ & 0.917 & 59.696 & 40.078 & 0.000 \\
\hline At most 1* & 0.680 & 27.318 & 33.878 & 0.245 \\
\hline At most 2 & 0.530 & 18.123 & 27.132 & 0.418 \\
\hline At most 3 & 0.427 & 13.378 & 21.132 & 0.418 \\
\hline At most 4 & 0.314 & 9.050 & 14.265 & 0.282 \\
\hline At most 5* & 0.231 & 6.301 & 3.841 & 0.012 \\
\hline
\end{tabular}

Max-eigenvalue test indicates 3 cointegrating eqn(s) at the 0.05 level.

* denotes rejection of the hypothesis at the 0.05 level.

**MacKinnon-Haug-Michelis (1999) p-values.
$<$ Table 4> and <Table 5> suggest that three cointegrations exist among all variables at $5 \%$ significance level. Namely, there is a long-run relationship among them just like $<$ Table $6>$ shows.

$<$ Table 6> Long-run cointegrating equation

\begin{tabular}{|c|c|c|c|c|c|}
\hline $\log R e r$ & $\log$ Wage & $\log M_{1}$ & $\log G d p$ & $\log G$ & $\log C p i$ \\
\hline 1.000 & -0.198 & 0.548 & 1.071 & -1.218 & -0.395 \\
\hline
\end{tabular}

Specific equation gives:

$$
\begin{aligned}
\log \operatorname{Re} r= & 1.071 \log G d p+0.548 \log M_{1}-1.218 \log G \\
& -0.395 \log C p i-0.198 \log \text { Wage }
\end{aligned}
$$

From equation (14), it can be concluded that $\log R e r$ has a long-run relationship among them. Specifically, 1\% increase in $\log G d p$ can result in $1.071 \%$ increase inlogRer; And $1 \%$ increase inlog $M_{1}$ can result in $0.548 \%$ increase in $\log$ Rer. Conversely, $1 \%$ increase in $\log G$ will lead to $1.218 \%$ fall in $\log R e r ;$ And $1 \%$ increase in $\log C p i$ will lead to $0.395 \%$ fall in $\log R e r$; Also, $1 \%$ increase in log Wage will lead to $0.198 \%$ fall in $\log R e r$.

\subsection{Impulse response function}

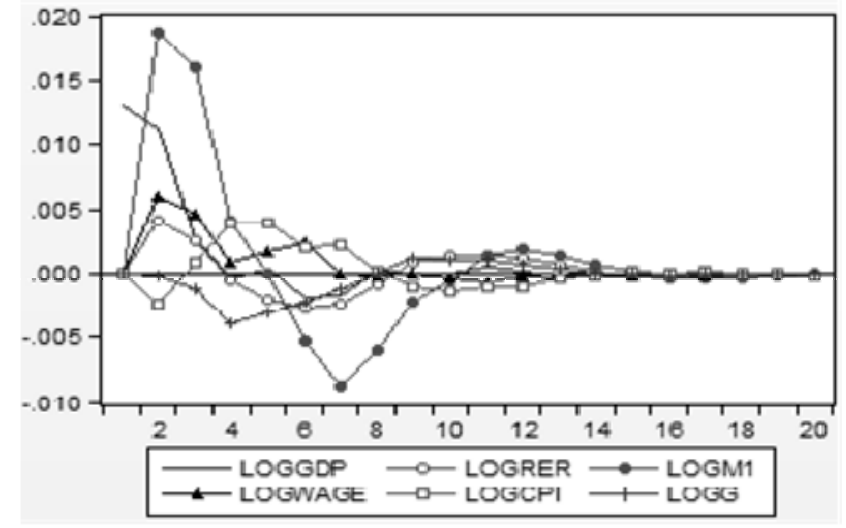

<Figure 1> Response of $\log G d p$ to Cholesky One S. D. Innovations

The impulse response functions show the reaction of the different variables' impulse to others. <Figure 1> implies that an increase in the $\log R e r$ results in an increase in $\log G d p$, and it will arrive at the maximum at lag 2. After lag 2, it will fall. So, a conclusion can be concluded that a depreciation of the real exchange rate can facilitate an increase in the output in the short time; And an increase in $\log M_{1}$ also can accelerate a significant increase in output and up to the maximum at lag 2. As time goes by, its shock on output will reduce gradually. Especially, its shock turns negative and up to minimum at lag 5. Then its impulse rebounds to be positive; Also, an increase in log Wage also can 
accelerate an increase in output and up to the maximum at lag 2. And its impulse always keeps positive in the short run; Conversely, an increase in $\log C p i$ can lead to a decrease in output and up to the minimum at lag 2 . It indicates that $\log C p i$ has a negative effect on output in the short run. In fact, its impulse will turn positive in the long run; And an increase in $\log G$ will result in a decrease in output and up to the minimum at lag 4 . Then its impulse will turn positive. Finally, as the impulse from itself, it has a negative effect on itself in the short run and up to minimum at lag7. Then it will disappear gradually.

\section{Variance Decomposition}

Variance decomposition measures the contribution of each explanatory variable to the expected change of explained variable. It is useful in assessing how changes to economic variables reverberate through a system.

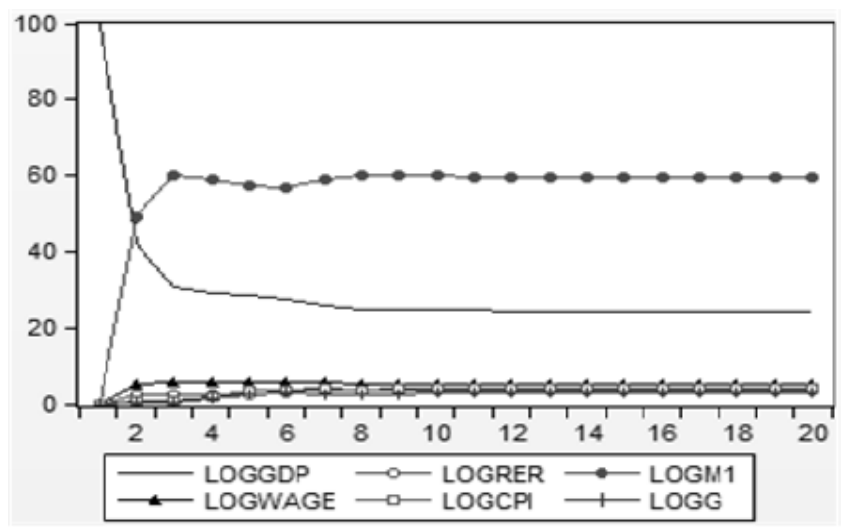

<Figure 2> Variance Decomposition of $\log G d p$

\section{References}

Ardic, O. P. (2006). Output, the Real Exchange Rate, and the Crises in Turkey. Topics in Middle Eastern and North African Economies, MEEA Online Journal, 8, 445-456.

Bahmani-Oskooee, M., \& Hajilee, M. (2009). The J-Curve at industry level: Evidence from Sweden-US trade. Economic Systems, 33(1), 83-92.

Bahmani-Oskooee, M., \& Hegerty, S. W. (2009). The effects of exchange-rate volatility on commodity trade between the United States and Mexico. Southern Economic Journal, 75(4), 1019-1044.

Bahmani-Oskooee, M., \& Kandil, M. (2009). Are devaluations contractionary in MENA countries?. Applied Economics, 41(2), 139-150.
$<$ Figure 2> reveals the variance decomposition of $\log G d p$. The change of $\log G d p$ is mainly from the impulse of $\log M_{1}$ up to $60 \%$. For others, its self impulse is up to $24 \%$; The impulse of $\log$ Wage is up to $5 \%$; The impulse of $\log G$ is up to $3 \%$; The impulse of $\log C p i$ is up $4 \%$ and the impulse of $\log \operatorname{Rer}$ is also $4 \%$.

\section{Conclusion}

This paper aims to verify the relationship between the real exchange rate and the output in China, which is based on the macroeconomic equilibrium theory. The results of cointegration test indicates that there is a long-run relationship between two of them. Specifically, if the real exchange rate changes by $1 \%$, the output will change by $0.934 \%$. Also, the impulse response function displays that the real exchange rate has a positive effect on output. However, the variance decomposition demonstrates that the real exchange rate only has a short-run effect on output, and its effect will be not held in the long run.

The result of this study implies that an increase in the real exchange rate will result in an increase in the output in the short run. However, it also proves that this kind of mechanism cannot work in the long run. The reason is that the Balassa-Samuelson Hypothesis works in the long run in China. Moreover, this paper indicates that the total supply and the total demand can promote the economic growth. Also, the fiscal policy and the money policy play a significant role in economic growth in China.

Bleakley, H., \& Cowan, K. (2008). Corporate dollar debt and depreciations: Much ado about nothing?. The Review of Economics and Statistics, 90(4), 612-626.

Bleaney, M., \& Vargas, L. C. (2009). Real exchange rates, valuation effects and growth in emerging markets. Open Economies Review, 20(5), 631.

Blecker, R. A., \& Razmi, A. (2007). The fallacy of composition and contractionary devaluations: output effects of real exchange rate shocks in semi-industrialized countries. Cambridge Journal of Economics, 32(1), 83-109.

Di Nino, V., Eichengreen, B., \& Sbracia, M. (2011). Real Exchange Rates, Trade, and Growth: Italy 
1861-2011. Economic History Working Papers 10, Bank of Italy, Economic Research Department.

Gala, P. (2007). Real exchange rate levels and economic development: theoretical analysis and econometric evidence. Cambridge Journal of economics, 32(2), 273-288.

Gala, P., \& Lucinda, C. R. (2006). Exchange rate misalignment and growth: old and new econometric evidence. Revista Economia, 7(4), 165-187.
Pesaran, M. H. (2006). Estimation and inference in large heterogeneous panels with a multifactor error structure. Econometrica, 74(4), 967-1012.

Rapetti, M., Skott, P., \& Razmi, A. (2012). The real exchange rate and economic growth: are developing countries different?. International Review of Applied Economics, 26(6), 735-753.

Rodrik, D. (2008). The real exchange rate and economic growth. Brookings papers on economic activity, 2008(2), 365-412. 